\title{
ANALYSING THE DETERMINANTS, CONSTRAINTS AND OPPORTUNITIES OF SMALLHOLDER FARMERS' ACCESS TO INPUT MARKETS: EVIDENCE FROM NORTHERN GHANA
}

\author{
Abdulai Adams $^{1 \bowtie}$, Charity Osei-Amponsah ${ }^{2}$, Emmanuel Tetteh Jumpah $^{1}$ \\ ${ }^{1}$ CSIR - Science and Technology Policy Research Institute, Accra, Ghana \\ ${ }^{2}$ International Water Management Institute, Accra, Ghana
}

\begin{abstract}
Smallholder farmers face multiple constraints in accessing input markets. This study seeks to understand the dynamics that influence input markets in northern Ghana and the opportunities that exist for smallholder farmers to increase their productivity and welfare. Using a random sample of 448 households, the study applied the probit and non-parametric methods in identifying the factors that influence farmers' access to input markets and the key constraints faced by them. The results show that access to extension services, access to finance, distance to the nearest input market, and input source are significant factors that would be likely to influence farmers' access to input markets. Lack of finance, poor road network, and low prices of output are the main critically ranked constraints limiting farmers' access to input markets. Policy initiatives should be geared toward strengthening extension service delivery, farmer education on inputs, improving feeder roads, and encouraging private sector participation in input markets. Available opportunities to leverage on and improve farmers' access to input markets include the governments' input subsidy programmes, existing large-scale agricultural projects, private agricultural companies with contract farming models, and extensive network of input dealers and aggregators in the communities. These findings are relevant for farmers, input dealers and policy makers working to improve farmers' access to input markets.
\end{abstract}

Keywords: determinants, constraints, market access, smallholder farmers, input markets, northern Ghana

\section{INTRODUCTION}

Agriculture remains a key sector in Ghana's development agenda and it accounted for $20.2 \%$ of the national Gross Domestic Product (GDP) in 2016 (Ministry of Finance and Economic Planning, 2017). About $80 \%$ of the total agricultural output in Ghana is attributed to smallholder farmers who continue to use rudimentary tools and methods in production. Nonetheless, food crop production by smallholder farmers has increased in recent years due to expanded land area under cultivation, adoption of improved varieties, expansion in extension services delivery, and increased access to inputs (Jatoe, 2015; MOFA, 2017). However, agricultural productivity remains low with the simultaneously increasing use of diversified strategies by farm households such as livestock rearing, engaging in off-farm activities, growing vegetables, food processing, and managing microbusinesses or shops for sustained livelihoods (Nkegbe, 2018).

Smallholder farmers faces multiple constraints in both production and marketing, which often leads to low incomes and welfare. Production challenges include declining soil fertility, land degradation, low access to modern inputs, effects of climate change and its impact on food and nutrition insecurity (MOFA, 2017;

\footnotetext{
$\bowtie$ Research Scientist, CSIR - Science and Technology Policy Research Institute, Box CT 519, Cantonments, Accra, Ghana, e-mail: boginah@yahoo.com; http://orcid.org/0000-0002-8820-0925
} 
Adams, A., Osei-Amponsah, C., Jumpah, E. T. (2020). Analysing the determinants, constraints and opportunities of smallholder farmers' access to input markets: evidence from northern Ghana. J. Agribus. Rural Dev., 2(56), 133-143. http://dx.doi. org/10.17306/J.JARD.2020.01286

Clay and King, 2018). The food insecurity and vulnerability issue is high in northern Ghana (28\% for Upper East Region; $16 \%$ for Upper West Region; $10 \%$ for Northern Region) as revealed by a study (WFP, 2012). Access to markets and the use of chemical fertilizers have been found relevant in explaining dietary diversity. Producers' access to markets is therefore important in ensuring sustained food and nutrition security, raising the incomes of households to meet essential needs and assure investment in farm and off-farm activities.

The government of Ghana, with support provided by international development agencies, have been implementing various programmes (mechanisation services, strengthening extension service delivery, and increasing farmers' access to inputs at an affordable rate) aimed at boosting productivity and minimising the constraints faced by smallholder farmers. For instance, the seed and fertilizer subsidy re-introduced in 2008, which has attracted a higher share of government expenditure on agriculture. Various reports revealed that between 2008 and 2016, an estimated total of 947,482 metric tonnes of fertilizer was subsidised at a cost of Gh $\phi 554.33$ million (MOFA, 2010; 2017). However, the subsidy programme is challenged with delays in payment to seed and fertilizer suppliers, delays in government announcements about the programme, inability of seed suppliers to provide the quantities demanded, and input diversion to neighbouring countries (Banful, 2009). Also, subsidy levels have declined for all fertilizer types over the years (40\% in 2009 to $20 \%$ in 2015) and issues of low quality of fertilizer input resulting in crop damage were reported (Benin et al., 2013). Effective control measures are needed to address concerns raised regarding the financial sustainability and impact of the subsidy on productivity (Chinsinga and O'Bien, 2008; Druihe and Barreiro-Hurle, 2012). On the contrary, studies that analysed the impact of input subsidy programmes on production and gender revealed positive outcomes (Fisher and Kandiwa, 2014; Jayne et al., 2018).

Whilst fertilizer subsidy undoubtedly lowers production costs and increases access, efficient use of inputs which is much more important cannot be guaranteed (Snapp et al., 2014). Low quality of soils coupled with low crop response rates to fertilizers, especially the inorganic ones, are key problems associated with fertilizer use in Africa (Ricker-Gilbert and Jayne, 2015; Sheahan et al., 2013). Wiredu et al. (2015) observed that input subsidy is not the best instrument for improving farm households' productivity, but that intensification of farmer training on sustainable land use practices and the introduction of labour-saving technologies should be the focus. Previously, Vanlauwe, et al. (2011) highlighted the need for complementary investments in water and soil management for efficient use of fertilizers, arguing that seed and inorganic fertilizers subsidies alone are unlikely to yield increases in productivity. The adoption of integrated soil fertility management practices offers a useful approach in overcoming the problem of low productivity (IFDC, 2012).

Meanwhile, McArthur and McCord (2017) revealed the importance of inputs (water, fertilizer, and improved seeds) in increasing yields and stimulating structural change in agriculture. Kelly et al. (2003) explored ways in which access to inputs could be expanded in Africa sustainably for continuous growth of private input markets. Input use was found as part of the solution to addressing poverty and food insecurity, highlighting the role that governments need to play in expanding input access. Asfaw et al. (2016) revealed that households' wealth, level of education, labour availability, and weather variability are the key determinants of modern input use. Technological progress and input deepening are reported to account for the observed moderate increases in irrigation productivity in US agriculture ( $\mathrm{Nju}$ ki and Bravo-Ureta, 2019). This suggests that the choice of technology adopted in production, financial position, and location factors influence farmers' access to inputs.

Furthermore, agricultural financing is one critical area that affects smallholder farmers' access to input markets and productivity. Adjognon et al. (2017) found that financing of modern input purchases by farmers took place mainly through using revenues generated from crop sales and off-farm activities. Sulemana and Adjei (2015) revealed the positive effects of microcredit on agricultural modernisation, suggesting that credit influences access to input markets. Ksoll et al. (2016) found that savings and credit received through memberbased associations led to improvements in the use of fertilizers. However, Sheahan and Barrett (2017) reported limited use of credit in purchasing agricultural inputs, which in most cases was non-existent.

This study extends the input market literature by analysing the factors that influence farmers' access to input markets, constraints and opportunities with focus on three commodities (maize, cowpea and livestock) that are of growing importance for vulnerable households 
Adams, A., Osei-Amponsah, C., Jumpah, E. T. (2020). Analysing the determinants, constraints and opportunities of smallholder farmers' access to input markets: evidence from northern Ghana. J. Agribus. Rural Dev., 2(56), 133-143. http://dx.doi. org/10.17306/J.JARD.2020.01286

Table 1. Variable definitions and measurement

\begin{tabular}{llc}
\hline \multicolumn{1}{c}{ Variable } & \multicolumn{1}{c}{ Description/Measurement } & $\begin{array}{c}\text { Expected } \\
\text { Effects }\end{array}$ \\
\hline Access to inputs (AIP) & 1 if a farmer has access to inputs locally, 0 otherwise & +- \\
Sex of Respondent (SEX) & 1 if a respondent is male, and 0 otherwise & +- \\
Association membership (ASS) & 1 if a farmer belongs to any producer/marketing/processing group, and 0 otherwise \\
Extension Services (EXT) & 1 if a farmer has access to extension services, and 0 otherwise & + \\
Access to financial Services (FIN) & 1 if a farmer has access to financial services (savings, loans) locally, and 0 otherwise & + \\
Distance to Market (DIS) & Average distance to the nearest input/output market in kilometres & $+/-$ \\
Market Availability (MKT) & 1 if there is local market for inputs, and 0 otherwise & + \\
Input Sources (INP) & 1 if a farmer uses seeds from own production, and 0 otherwise & + \\
\hline
\end{tabular}

Source: literature review.

in northern Ghana. Empirical evidence on the nature of constraints and opportunities available locally to help minimise the effects of these constraints on the chosen commodity value chains is lacking in the input access space. This study, therefore, aims to bridge this gap.

\section{METHODOLOGY}

Data, variable description, and measurement The data used for this study was collected from a household survey conducted between February and May 2019, covering six (6) districts across northern Ghana. Two (2) districts each were purposively selected from the Upper East, Upper West, and Northern regions of Ghana, to draw insights into the determinants of input market access and constraints faced by farmers. A total of 13 rural communities were covered based on a programme ${ }^{1}$ intervention that seeks to promote sustainable intensification practices among farming households for increased food security and incomes. A total of 448

${ }^{1}$ The Africa Research in Sustainable Intensification for the Next Generation is a USAID-sponsored programme under the Feed the Future Initiative. The programme is being implemented in Ghana and Mali in the West Africa sub-region. In Ghana, the major crops are maize, cowpea and small ruminants and the programme aims to increase the involvement of women and youth in the production, marketing and consumption of theses commodities. The project commenced in 2017 and will end in 2021. Significant advances have been made in the development, dissemination, and adoption of various crops and livestock technologies for increased productivity and incomes of farmers. households were randomly selected and data collected using programmable tablets. The communities were first clustered into beneficiary and non-beneficiary communities. Systematic random sampling was then applied to each community and the final households were selected from a list for the interviews. In addition, 12 focus group discussions (FGDs) and 24 key informant interviews (KIIs) were conducted and in-depth qualitative information on input supply, input use, constraints, opportunities, and farmers' access to inputs was collected. The FGDs and KIIs enabled the involvement of a wide range of stakeholders and participants/institutions were selected based on the nature of services they offer to farmers, sex, and knowledge of the issues affecting smallholders' access to input markets. The main variables included in the analysis, their measurements, and expected effects are summarised in Table 1. This is followed by the variable explanations and supportive evidence/justifications based on the available literature.

Access to inputs is used as a proxy for input market access and it serves as the dependent variable in this study. Households' access to good quality inputs in a timely manner is important in catalysing increased production and productivity. However, agricultural inputs use decisions is affected by policy, biophysical and farm characteristics (Sheahan and Barett, 2017). Input use is also directly related to the adoption and uptake of technologies as well as output levels (Wongnaa, 2016). Both positive and negative effects can result from access to inputs. Gender has been shown to influence access to input use as females tend to use fewer inputs compared 
Adams, A., Osei-Amponsah, C., Jumpah, E. T. (2020). Analysing the determinants, constraints and opportunities of smallholder farmers' access to input markets: evidence from northern Ghana. J. Agribus. Rural Dev., 2(56), 133-143. http://dx.doi. org/10.17306/J.JARD.2020.01286

to their male counterparts (Fisher and Kandiwa, 2014; Sheahan and Barrett, 2017). However, females tend to dominate in the marketing of agricultural commodities (Amaya and Alwang, 2011).

Association membership refers to a situation where a smallholder farmer belongs to a production/ processing/ marketing group. Membership to a farmer-based organisation influences technological and varietal adoption by farmers (Awotide et al., 2016). Extension services/contact with farmers have an impact on the use of productivity enhancing technologies and inputs (Wongnaa, 2016) and they constitute a key determinant of technical efficiency in production (Nmadu and Marcus, 2013). Extension contact is expected to influence positively the input use and market access.

Access to financial services (savings and loans) enable farming households to meet production costs, especially at the beginning of the growing season. Mechanisation services constitute one area where farmers often struggle to meet the cost in an effort to structurally adjust their farming operations from subsistence to commercially-based. As such, mechanisation levels in African agriculture remain very low (Sheahan and Barett, 2017). Formal financial institutions are generally unwilling to grant loans to farmers for various reasons (limited or no collateral, bad credit history, among others). Tied output-labour arrangements, and input credit financing by market women and input dealers offer some perspective to farmers. Access to credit significantly impacts input access and use, and promotes efficiency in production (Nmadu and Marcus, 2013; Wongnaa, 2016). We expect access to financial services to positively impact the access to inputs.

Distance to the nearest source of input affects the intensity of adoption of improved rice varieties (Awotide et al., 2016). Distance matters as far as enabling farmers to have access to input markets is concerned. Where extensive input distribution network exists, farmers tend to have better access to inputs. However, in situations of limited input sales points at the community level, farmers have to cover long distance to input markets. Distance disconnects villages from input supply chains and impacts directly the input costs incurred by farmers (Chianu et al., 2008). Low input use by farmers has been linked to remoteness of farmer's location, production risk prevalent in the location and the agricultural production potential of the zone (Crawford et al., 2003). Farming households situated in designated agricultural zones would likely have better access to input markets compared to those in consuming areas. We, therefore, anticipate distance to have both positive and negative effects on access to inputs.

Market availability locally can increase farmers' access to input markets. Input shops are limited in most rural areas and farmers tend to rely on traders and other input dealers who come to sell their inputs at local markets. Availability of ready markets positively impacts the input use and technology uptake (Wongnaa, 2016). Positive effects are anticipated to be visible in the area of input market access. Finally, Input Source has an effect on productivity. Farmers using improved seeds from accredited sources are less likely to have access to input market in rural communities than those using seeds from previous harvests. Awotide et al. (2016) reported that access to improved seeds influences farmers' participation in markets. The source of fertilizer has been shown to have an impact on its demand and use by farmers (Ricker-Gilbert and Jayne, 2015). Both positive and negative effects are expected to appear in the field of input market access.

\section{Analytical framework}

This study used the probit model, together with a nonparametric method in analysing the factors that determine farmers' access to input markets, constraints faced and the opportunities that arise in the input market space. Theoretically, the decision of a household to access farm inputs (seeds, fertilizers, veterinary medications, etc.) is influenced by various factors (institutional, techni$\mathrm{cal}$, and socio-economic). Assuming the latent variable, represents the decision of a household to access inputs from the market and represents independent variables that predict farmers' access to inputs, the quantitative response model can be represented as:

$$
y_{i}=\beta^{\prime} X_{i}+\varepsilon_{i} ; \varepsilon \sim N\left(0, \sigma^{2}\right)
$$

where $\beta$ is the coefficient of parameter estimates and $\varepsilon_{i}$ is the error term. The Ordinary Least Squares (OLS) approach is inappropriate in analysing binary choice models as the occurrence of an event has a non-linear probability (Collett, 1991) and the estimated probabilities generated could be outside the usual range ( 0 and 1$)$. The use of logit or probit model is useful in such situations. However, studies revealed that the probit model performs better even with small samples than the logit model (Anang et al., 2015; Sebopetji and Belete, 2009), hence the choice for this study. 
Adams, A., Osei-Amponsah, C., Jumpah, E. T. (2020). Analysing the determinants, constraints and opportunities of smallholder farmers' access to input markets: evidence from northern Ghana. J. Agribus. Rural Dev., 2(56), 133-143. http://dx.doi. org/10.17306/J.JARD.2020.01286

$$
y_{i}=\left\{\begin{array}{l}
1 \text { if } y_{i}{ }_{i} \geq 0 \\
0 \text { if } y_{i}{ }_{i} \leq 0
\end{array}\right.
$$

Where $y^{*}{ }_{i}$ values are positive, $y_{i}=1$ for all those cases and where $y_{i}^{*}$ assumes zero or negative values, $y_{i}=0$ for all those cases.

$$
P_{r}\left(y_{i}=1 / X_{i}\right)=\varnothing\left(\beta^{\prime} X_{i}\right)
$$

where $y_{i}$ is farmers' access to input markets which ranges between 0 and $1, \varnothing$ depicts the cumulative distribution function (cdf) of the standard normal distribution. $\varepsilon_{i}$ is normally distributed, hence $\varnothing$ is a normal cdf (Greene, 2002). The assumption is that values of $y_{i}$ are determined by latent continuous variable and only values of 0 and 1 are observed (Sebopetji and Belete, 2009).

$$
P_{r}\left(y_{i}=1 / X_{i}\right)=\varnothing\left(\beta^{\prime} X_{i}\right)=\int_{-\infty}^{\beta^{\prime} X_{i}} \varnothing(t) \partial t
$$

where $\varnothing(t)$ is the standard normal distribution. The marginal effects of change in $X_{i}$ on $y_{i}$ following Maddala (1983) and Greene (2002) are expressed by:

$$
\frac{\partial E\left(y_{i} x_{i}\right)}{\partial x_{i}}=\frac{\partial E\left(\varnothing\left(\beta^{\prime} x_{i}\right)\right)}{\partial x_{i}}=\varnothing\left(\beta^{\prime} X_{i}\right) \beta
$$

The empirical model estimated in determining the factor that influences farmers' access to input markets is of the following formula:

$$
\begin{gathered}
P_{r}\left(y_{i}=1\right)=\beta_{0}+\beta_{1} S E X_{i}+\beta_{2} A S S_{i}+\beta_{3} E X T_{i}+ \\
\beta_{4} F I N_{i}+\beta_{5} M K T_{i}+\beta_{6} D I S_{i}+\beta_{7} I N P_{i}+\varepsilon_{i}
\end{gathered}
$$

where $\beta_{0}$ is the constant term, $\beta_{i}{ }_{i} s$ are parameters to be estimated and $\varepsilon_{i}$ is the random error term.
A nonparametric approach, Kendall's Coefficient of Concordance was employed to establish the main constraints faced by farmers in accessing input markets. Constraints associated with input markets were compiled through literature review and farmers were then asked to rank (from the most important to the least important) the constraints, based on their experience. This approach has been widely used in assessing the level of agreement among a set of observations by providing ranks. The sum of ranks was then computed though most empirical studies utilising the mean rank. Kendall Coefficient of Concordance (W) is given as follows:

$$
W=\frac{12 S^{\prime}-3 p^{2}(n+1)^{2}}{p^{2}\left(n^{3}-n\right)-p T}
$$

where $p=$ the number of observations, $n=$ the number of constraints ranked, $S=$ the sum of squares, and $t=$ the correction for ties. The value of $W$ is tested using the chi square, $X^{2}=p(n-1) W$, with the null hypothesis of no agreement among the ranks of the constraints as provided by the observations. Based on the level of significance, a decision to accept or reject is then made. If significant, then the null hypothesis is rejected.

\section{RESULTS AND DISCUSSION}

\section{Descriptive Statistics}

More males (78\%) than females were included in the survey. Table 2 shows that on average $68 \%$ of farmers had access to various inputs (seeds, fertilizers, and pesticides). However, the use of seeds from farmers' own

Table 2. Descriptive statistics

\begin{tabular}{lcccc}
\hline \multicolumn{1}{c}{ Variable } & Mean & SD & Minimum & Maximum \\
\hline Access to inputs (AIP) & 0.680180 & 0.467461 & 0.0 & 1.0 \\
Sex of respondent (SEX) & 0.780269 & 0.414996 & 0.0 & 1.0 \\
Association Membership (ASS) & 0.264574 & 0.442098 & 0.0 & 1.0 \\
Extension Services (EXT) & 0.757848 & 0.429350 & 0.0 & 1.0 \\
Access to Financial services (FIN) & 0.269006 & 0.444745 & 0.0 & 1.0 \\
Distance to market (DIS) & 18.12670 & 16.37680 & 2.0 & 54.0 \\
Market availability (MKT) & 0.520179 & 0.500717 & 0.0 & 1.0 \\
Input Sources (INP) & 0.677130 & 0.468625 & 0.0 & 1.0 \\
\hline
\end{tabular}

Source: estimation from field data, 2019. 
Adams, A., Osei-Amponsah, C., Jumpah, E. T. (2020). Analysing the determinants, constraints and opportunities of smallholder farmers' access to input markets: evidence from northern Ghana. J. Agribus. Rural Dev., 2(56), 133-143. http://dx.doi. org/10.17306/J.JARD.2020.01286

production for planting was high $(67 \%)$ among farmers. Only about $26 \%$ of farmers belong to an association (production, marketing, or processing). This suggests that most farmers are currently not benefiting from the advantages that are related to belonging to a farmer association such as higher prices/incomes from collective marketing, bulk delivery of inputs at a lower cost, peer monitoring, etc. Access to extension services was generally high $(75 \%)$, due to the involvement of private businesses and NGOs in the agricultural sector. However, access to veterinary medications and services from MOFA was very low. Access to financial services remains a challenge as only $26 \%$ of the respondents had access in 2018 production season. Approximately a half (52\%) of the respondents had access to markets locally. The primary marketing channels used by farmers were village markets $(62.8 \%)$, farm gate $(15.3 \%)$, and private sales $(19.6 \%)$. The use of regional and district markets for inputs was low. The average distance to the nearest input market was 18 kilometres. Improving farmers' access to input markets would mean that institutions mandated to provide the needed services would have to implement strategies that adequately address these issues.

\section{Determinants of farmers' access to input markets}

Probit estimates of the determinants of farmers' access to input markets are presented in Table 3, with the marginal effects associated. In order to facilitate the interpretation, we utilised the marginal effects in the interpretations. Out of the seven independent variables modelled, four were found to be significant. In Table 3, p-values show that with the exception of sex, market availability locally and association membership, all variables included were significant. The pseudo $\mathrm{R}^{2}$ value of 0.419 reveals that the independent variables significantly influence farmers' access to input markets.

Access to extension services has a negative and significant effect on farmers' access to input markets. The marginal effect of having access to extension services on input market is -0.275 . This shows that the probability of a farmer having access to input market declines by $28 \%$ given that the farmer has access to extension services. This is against the theoretical expectation since extension service access is anticipated to result in a better provision of information to farmers on where to get quality inputs, the prevailing input prices, efficient use of inputs, etc. This may be attributed to the poor extension contact with farmers due to low staff numbers and poor logistics which has led to the adoption of the unified extension services delivery (based largely on the use of mass media instead of farm and home visits).

Access to financial services is critical in enabling farmers' access to input markets. The marginal effect of having access to financial services on input market

Table 3. Probit results of the factors that influence farmers' access to input markets

\begin{tabular}{lcccc}
\hline \multicolumn{1}{c}{ Variable } & Marginal effects & Std. Err. & $\mathrm{z}$ & $\mathrm{P}>|\mathrm{z}|$ \\
\hline Sex (SEX) & 0.214 & 0.508 & 0.42 & 0.673 \\
Association membership (ASS) & -0.128 & 0.089 & -1.44 & 0.149 \\
Access to extension services (EXT) & $-0.275^{* * *}$ & 0.095 & -2.89 & 0.004 \\
Access to financial services (FIN) & $-0.246^{* *}$ & 0.120 & -2.05 & 0.04 \\
Market Availability (MKT) & -0.045 & 0.096 & -0.47 & 0.64 \\
Distance to input market (DIS) & $-0.001^{* *}$ & 0.0005 & -2.01 & 0.044 \\
Input Sources (INP) & $0.118^{*}$ & 0.062 & 1.9 & 0.057 \\
No. of Observations & 448 & & \\
Prob $>$ Chi $^{2}$ & 0.000 & & & \\
Pseudo R & & & & \\
\hline
\end{tabular}

Note: $* * *, * *$, and $*$ mean significant at $1 \%, 5 \%$ and $10 \%$ respectively.

Source: Estimation from field data, 2019. 
Adams, A., Osei-Amponsah, C., Jumpah, E. T. (2020). Analysing the determinants, constraints and opportunities of smallholder farmers' access to input markets: evidence from northern Ghana. J. Agribus. Rural Dev., 2(56), 133-143. http://dx.doi. org/10.17306/J.JARD.2020.01286

is -0.246 (Table 3 ). This means that the probability of a farmer having access to input markets decreases by $24.5 \%$ given that the farmer has access to financial services. This highlights the importance of financial services and their usage by farmers in achieving greater yields. The inverse relationship between access to input markets and financial services could be explained by income diversification and credit misuse. It could also be attributed to the general low credit for agriculture as observed in most African countries. This outcome is at variance with the observation that agricultural outputs increase in response to higher investments (Ksoll et al., 2016), of which access to finance constitutes an integral part.

Distance to input markets is negatively and significantly related to farmers' access to input markets. The marginal effect of distance on input market access is -0.001 . The implication is that distance matters in farmers' access to input markets in northern Ghana since an increase in distance would be likely to result in decreased access to input markets by farmers and vice versa. This observation strengthens the findings of Singh (2018) that nearness to milk production centres influences the decision of smallholder milk farmers to sell directly to consumers since farmers find it difficult to sell directly to distant consumers located far away from the production centres. Similarly, Asfaw et al. (2016) reported that the greater the distance, the less likelihood that farmers will use modern inputs. Distance to the nearest market therefore impacts the input use and technology adoption.

Finally, the source of inputs has positive and significant effects on farmers' access to input markets. The marginal effect of using seeds and other inputs from farmers' own fields/ sources on input market access is 0.118. This suggests that, where farmers have control over input sources, the likelihood of having access to input markets increases. The probit result of Table 3 showed clearly that with farmers using seeds from their "own production" sources, the probability of having access to input markets increases by $12 \%$. Sources of inputs to farmers thus influence their input market access.

Variables found to be insignificant in influencing farmers' access to input markets include sex and association membership, although studies by Awotide et al. (2016) and Sheahan and Barrett (2017) found contrary results for association membership and gender respectively.

\section{Constraints to input market access}

Table 4 presents a list of constraints and farmers assessment of the extent to which the constraints affect input market access. These factors were identified through literature review and interaction with some sector stakeholders regarding the efficient functioning of agricultural input markets in the country. Ranking of the constraints was performed by farm households based on their experience in input markets. A set of constraints was listed in tabular form and each respondent was asked to rank these constraints from the highest to the lowest. The individual scores obtained through the ranking were then pooled together and analysed quantitatively.

Table 4. Constraints to input markets

\begin{tabular}{lll}
\hline \multicolumn{1}{c}{ Constraint } & \multicolumn{1}{c}{ Mean Score } & Rank \\
\hline Lack of finance & 3.27 & $1^{\text {st }}$ \\
Poor road networks & 4.13 & $2^{\text {nd }}$ \\
Low prices of outputs & 4.20 & $3^{\text {rd }}$ \\
Lack of grading and standardisation & 4.68 & $4^{\text {th }}$ \\
Poor market infrastructure & 4.75 & $5^{\text {th }}$ \\
Lack of ready markets & 4.97 & $6^{\text {th }}$ \\
Low bargaining skills/power of farmers & 5.00 & $7^{\text {th }}$ \\
Weak crop and livestock value chains & 5.00 & $7^{\text {th }}$ \\
\hline
\end{tabular}

$\mathrm{N}=448$.

Source: Field data, 2019.

Quantitative analysis of the ranked constraints using the Kendell Coefficient of Concordance (W) approach revealed that the lack of finance, poor road networks and low prices of outputs are the main constraints affecting farmers' access to input markets. The overall test statistics of $\mathrm{W}$ showed that at a chi-square value of 313.746 with degrees of freedom (7), the value of $\mathrm{W}$ is asymptotically significant at 0.000 . The value of $\mathrm{W}$ was 0.801 , which suggests that there was strong agreement among the respondents regarding the overall ratings.

The lack of finance is the constraint ranked first by farmers accessing input markets. This is not surprising against the backdrop that transaction costs are high and input costs are mainly met through self-financing by farmers. Apart from farmers, agro-input dealers face 
Adams, A., Osei-Amponsah, C., Jumpah, E. T. (2020). Analysing the determinants, constraints and opportunities of smallholder farmers' access to input markets: evidence from northern Ghana. J. Agribus. Rural Dev., 2(56), 133-143. http://dx.doi. org/10.17306/J.JARD.2020.01286

credit constraints which impede their service delivery to farmers especially those in remote villages who are often disconnected from input supply chains (Chianu et al., 2008). Furthermore, high costs of inputs affect the aggregate demand for inputs leading to lower yields and profitability of the farm enterprise (Crawford et al., 2003). Nmadu and Marcus (2013) reported that poor access to credit constitutes a key constraint facing ginger farmers in Nigeria.

The second most important constraint limiting farmers' access to input markets (Table 4) is the bad condition of roads that link farming communities to market centres. The bad road situation is often worsened by the raining season where some communities are completely cut off by water bodies, making it impossible for inputs to be transported to markets for sale. High transport costs $(53 \%)$ resulting from bad road networks have been noted as the main constraint facing agro-input dealers and cattle farmers (Chianu et al., 2008; Musemwa et al., 2008). Poor roads also inhibit farmers' access to output markets which has an impact on their incomes (Binge et al., 2019).

The third ranked constraint which limits farmers' access to input markets are the low prices of products, especially during the period of harvest (glut in markets). In this case, access to market needs to be conceptualised in the context of farmers participating in lucrative markets. In situations where the prices of outputs are so low that the revenue generated from the sale of products falls below the production costs incurred, farmers are said to be worse off. Low demand for output has been documented as a constraint to farmers' access to input markets (Chianu et al., 2008). Furthermore, poor quality and fluctuations in output prices are major constraints facing ginger farmers (Nmadu and Marcus, 2013). Binge et al. (2019) reported that low prices constitute a major marketing constraint facing small stock farmers.

Constraints that rank low among farmers were weak crop and livestock value chains, low bargaining skills of farmers, and lack of ready markets. This, however, does not mean that they do not affect farmers. For instance, the absence of guaranteed markets for farmers came up strongly during the focus group discussions and this is part of the lack of ready market issue.

\section{Input market opportunities for farmers and other value chain actors}

A number of opportunities were identified which could serve as a catalyst for transforming input markets for value chain actors, especially young men and women who have a chance to have better access to input markets with a view of increased productivity, incomes and employment. These opportunities were first identified through published strategic documents and studies that analysed the Planting for Food and Jobs (PFJ) Initiative as well as emerging opportunities and impact areas (see PFJ, 2017; Lambongany et al., 2019; Tanko et al., 2019; Ansah et al., 2020). The opportunities mapped out were then validated through FGDs and KIIs conducted in the communities. A synthesis of the extensive discussions held and the key outcomes (some of them critical) are presented and discussed below as potential areas for job creation:

- Planting for Food and Jobs (PFJ) Initiative: Various components (seed and fertilizer subsidy, warehousing, rearing for food and jobs, dam construction, and community extension components) of the PFJ programme were found useful in enabling farmers to gain easy access to input markets. For instance, the One village, One dam concept will support all year-round production, enabling farmers to use more inputs, create jobs along the production and marketing chain, and improve household food and nutrition security. The community extension component is anticipated to boost extension contact with farmers and improve the flow of production and marketing information among various actors in the extensionproduction-market chain. Positive impacts of the initiative in reducing households' expenditure in rice production and decreasing their income poverty levels have been documented in northern Ghana (Tanko, Ismail, and Sadiq, 2019). However, the fear that these initiatives were politically motivated and may not be sustained in the long run if there is change of power, lingers on with farmers.

- Leveraging on existing large agricultural projects: MOFA has implemented a number of bilateral agricultural projects (e.g. Northern Rural Growth Programme; Market Oriented Agriculture Programme (MOAP) aimed at improving rural infrastructure and enabling farmers' access to input and output markets. For instance, MOAP is jointly being implemented by GIZ and MOFA, aimed at educating farmers on high value crops with market demand, increasing farmers' access to seed and fertilizer inputs, and linking farmers and aggregators to local and international markets. Putting an emphasis on 
Adams, A., Osei-Amponsah, C., Jumpah, E. T. (2020). Analysing the determinants, constraints and opportunities of smallholder farmers' access to input markets: evidence from northern Ghana. J. Agribus. Rural Dev., 2(56), 133-143. http://dx.doi. org/10.17306/J.JARD.2020.01286

these market-based project interventions offers a potential in expanding input and output market access for farmers.

- Presence of input dealers, assemblers and aggregators (market actors): The presence of input dealers, assemblers and aggregators offers a huge potential to linking farmers to profitable input and output markets for target commodities (maize, cowpea, small ruminants). For instance, in the case of maize, processing companies such as Nestle Ghana Limited, World Food Programme, and poultry farmers association pursue bulk purchases through aggregators. These actors therefore play a critical role in linking producers to markets and they also prefinance the production of these commodities.

- Role of the private sector: Private agriculture businesses such as WIENCO Ghana Limited provide smallholder farmers with access to inputs, technical advice, guaranteed markets, and ensure product quality under contract farming arrangements. This addresses some of the multiple constraints faced by farmers as higher incomes and improved welfare of farmers have been documented for such schemes (ILO, 2017). These enterprises also create job opportunities in the transportation sector as both input and output are moved from urban to rural communities and vice versa. The input credit provided to farmers through the schemes at the beginning of the cropping season relieves farmers of the financial burdens (land preparation, input and labour costs, etc.) and enables them to shift resources to meet other pressing household needs.

- Institutional buyers: Farmers and farmer-based associations involved in production and produce aggregation need to be linked to institutional buyers and programmes (such as the school feeding program, hospitals, prisons etc.) for the supply of food items locally. This will have an impact on local production (input use) and enhance farmers' access to output markets. Where farmers are assured of guarantee markets, there is greater likelihood that they will see and approach farming as a business. Local government authorities (District Assemblies) have a role to play in ensuring that this works effectively.

- Livestock aggregation, processing and marketing: This offers a huge potential for the youth in northern Ghana. Experience shared by women groups revealed that a number of small ruminant projects implemented in the past (e.g. Livestock Development Project) had multiple effects on beneficiary households and the communities as a whole. With increased livestock population, the demand for veterinary medications and services is likely to go up. Livestock assembling is seen as a profitable venture for young males due to cross-regional trade in livestock markets within the country. Supporting the development of the small ruminant value chain offers some opportunities for livestock actors.

\section{CONCLUSION AND POLICY IMPLICATIONS}

The study revealed that smallholder farmers are faced with several constraints. Farmers' access to input markets remains a developmental challenge as productivity levels continue to fall below potential levels despite the numerous ongoing interventions by government, the private sector and development donor agencies in stimulating input and output markets. Understanding the dynamics that underlie input market access is critical in mapping out sustainable solutions for increased production and improving market access for smallholder farmers.

The study findings revealed that access to extension service, access to finance, distance to the nearest input market, and source of inputs are the main significant factors likely to influence smallholder farmers' access to input markets. Except the source of inputs, the marginal effects of all the other significant factors were negative, suggesting that input market access worsens with increased distance to the marketplace, access to credit and extension services. Policies should therefore be tailored towards improving these factors for greater input market access, especially for resource-poor farmers engaged in subsistence agriculture. As noted by Tanko, Ismail, and Sadiq, (2019), there is a need for the government to use the local media to promote the PFJ fertilizer subsidy and improved varieties for greater adoption, productivity and welfare of farmers. Ansah, Lambongany, and Donkoh (2020) provided recent evidence of the role of human and institutional capabilities that enhanced the participation of farmers in the PFJ programme and the need to develop them through the provision of infrastructure (roads, markets, etc.) especially in remote areas.

The major constraints ranked, limiting smallholder farmers' participation in input markets are the lack of finance, poor road networks and low prices of outputs. 
Adams, A., Osei-Amponsah, C., Jumpah, E. T. (2020). Analysing the determinants, constraints and opportunities of smallholder farmers' access to input markets: evidence from northern Ghana. J. Agribus. Rural Dev., 2(56), 133-143. http://dx.doi. org/10.17306/J.JARD.2020.01286

The policy implication of these results for stakeholders is to develop effective strategies and work towards eliminating these constraints. Strategies such as seeking private partnerships to make credit available to farmers, strengthening extension services delivery through increased investments in training and logistics could improve input market access. On-going initiatives in the agricultural sector that provide hope for farmers in terms of productivity increases and enhancing the welfare of farmers include the PFJ initiative (Lambongang, Ansah, and Donkoh, 2019; Tanko, Ismail, and Sadiq, 2019), leveraging on existing infrastructure and market-oriented projects, private agricultural projects with contract farming schemes (ILO, 2017), and the extensive network of input dealers, aggregators, and farmer-based organisations. Integrating these opportunities into the development of medium- to long-term plans at various levels would help improve farmer access to input markets.

One way through which this research could be extended is to quantitatively analyse smallholder farmers' access to output markets, especially in the face of weak farmer marketing cooperatives, limited guaranteed pricing, and poor enforcement of the market contracts.

\section{SOURCE OF FINANCE}

The source of funding for this research work came from the Africa RISING Project No. AID-BFS-G-11-00002, funded by the USAID under the Feed the Future Initiative.

\section{ACKNOWLEDGEMENTS}

The authors are grateful for the support received from the Africa RISING project team members, both in STEPRI and IITA Tamale offices, during data collection. We appreciate the support of Dr Fred Kizito and HoeschleZeledon Irmgard of IITA.

\section{REFERENCES}

Adjognon, S.G., Liverpool-Tosie, L.S.O., Reardon, T.A. (2017). Agricultural input credit in sub-Saharan Africa: Telling myth from facts. Food Policy, 67, 93-105.

Amaya, N., Alwang, J. (2011). Access to information and farmers market choices: The case of Potato in highland Bolivia. J. Agric. Food Syst. Comm. Dev., 1 (4), 35-53.

Anang, B.T., Sipilainen, T., Backman, S., Kola, J. (2015). Factors influencing smallholder farmers access to agricultural microcredit in northern Ghana. Afr. J. Agric. Res., 10 (24), 2460-2469.

Ansah, I.G.K., Lambongang, M., Donkoh, S.A. (2020). Ghana's planting for Food and Jobs Programme: A look at the role of capability in farmer's participation. J. Hum. Dev. Capab., 21(2), 161-182.

Asfaw, S., Di Battista, F., Lipper, L. (2016). Agricultural technology adoption under climate change in the Sahel: Micro-evidence from Niger. J. Afr. Econ., 25(5), 637-669.

Awotide, B.A., Karimov, A.A., Diagne, A. (2016). Agricultural technology adoption, commercialization and smallholder rice farmers' welfare in rural Nigeria. Agric. Food Econ., 4(3), 1-24.

Banful, A.B. (2009). Operational details of the 2008 fertiliser subsidy in Ghana: Preliminary Report. Ghana Strategy Support Programme (GSSP) Background Paper No. 18. Accra: IFPRI.

Benin, S., Johnson, M., Abokyi, E., Ahorbo, G., Jimah, K., Nasser, G., Owusu, V., Taabazuing, J., Tenga, A. (2013). Revisiting Agricultural input and farm support subsidies in Africa: The case of Ghana's mechanization, fertilizer, block farms and marketing programs. Discussion Paper No. 01300, IFPRI.

Binge, A., Mshenga, P., Kgosikoma, K. (2019). Production and marketing constraints of small stock farming: evidence from limid and non-limid farmers in Boteti subDistrict, Botswana. J. Agrib. Rural Dev., 3(53), 195-201.

Chianu, J.N., Mairura, F., Ekise, I., Chianu, J.N. (2008). Farm input marketing in western Kenya: challenges and opportunities. Afr. J. Agric. Res., 3(3), 167-173.

Chinsinga, B., O’Brien, A. (2008). Planting ideas: how agricultural subsidies are working in Malawi. African Research Institute.

Clay, N., King, B. (2018). Smallholders' uneven capacities to adapt to climate change amid Africa's 'green revolution': Case study of Rwanda's crop intensification program. World Dev., 116, 1-14.

Collett, D. (1991). Modelling binary data. London: Chapman and Hall.

Crawford, E., Kelly, V., Jayne, T.S., Howard, J. (2003). Input use and market development in sub-Saharan Africa: An overview. Food Polic., 28, 277-292.

Druilhe, Z., Barreiro-Hurle, J. (2012). Fertilizer subsidies in sub-Saharan Africa. ESA Working Paper 12-04, pp. 73. July 2012.

Fisher, M., Kandiwa, V. (2014). Can agricultural input subsidies reduce the gender gap in modern maize adoption? Evidence from Malawi. Food Polic., 45, 101-111.

Greene, W.H. (2002). Econometric analysis. New Jersey: Prentice Hall.

IFDC (2012). Ghana fertilizer assessment. In support of The African Fertilizer and Agribusiness Partnership.. 
Adams, A., Osei-Amponsah, C., Jumpah, E. T. (2020). Analysing the determinants, constraints and opportunities of smallholder farmers' access to input markets: evidence from northern Ghana. J. Agribus. Rural Dev., 2(56), 133-143. http://dx.doi. org/10.17306/J.JARD.2020.01286

ILO (2017). Improving market access for smallholder farmers: What works in out-grower schemes - evidence from Timor-Lester. Issue Brief No. 1.

Jatoe, J.B.D. (2015). Country profile on climate change, agricultural trade and food security in ECOWAS. Ghana Report. UNU-INRA.

Jayne, T.S., Mason, N.M., Burke, W.J., Ariga, J. (2018). Review: Taking stock of Africa's second-generation agricultural input subsidy programs. Food Polic., 75, 1-14.

Kelly, V., Akinwumi, A., Adesina, A.A., Gordon, A. (2003). Expanding access to agricultural inputs in Africa: A review of recent market developments experience. Food Polic., 28, 379-404.

Koppmair, S., Kassie, M., Qaim, M. (2016). Farm production, market access and dietary diversity in Malawi. Public Health Nutr., 20(2), 325-335.

Ksoll, C., Lilleor, H.B., Lonborg, J.H., Rasmussen, O.D. (2016). Impact of Village Savings and Loan Associations: Evidence from a cluster randomised trial. J. Dev. Econ., 120, 70-85.

Lambongang, M., Ansah, I.G.K., Donkoh, S.A. (2019). Participation and yield effect of Ghana's planting for Food and Jobs Programme Bunkpurugu-Yunyoo District. Ghana J. Agric. Econ. Agribus., 2(1), 86-96.

Maddala, G.S. (1983). Limited dependent and qualitative variables in econometrics. New York: Cambridge University Press.

McArthur, J.W., McCord, G.C. (2017). Fertilizing growth: Agricultural inputs and their effects in economic development. J. Dev. Econ., 127, 133-152.

Ministry of Finance and Economic Planning (2017). End-year report on the budget statement and economic policy of the republic of Ghana for the 2015 financial year. Ministry of Finance.

MOFA (Ministry of Food and Agriculture). (2010). Agriculture in Ghana: Facts and Figures. Government of Ghana Publications.

MOFA (Ministry of Food and Agriculture) (2017). Agricultural sector progress report 2016. Ministry of Food and Agriculture, Policy Planning, Monitoring and Evaluation Directorate.

Musemwa, L., Mushunje, A., Chimonyo, M., Fraser, G., Mapiye, C., Muchenje, V. (2008). Nguni cattle marketing constraints and opportunities in the communal areas of South Africa: Review. Afr. J. Agric. Res., 3(4), 239-245.

Njuki, E., Bravo-Ureta, B.E. (2019). Examining irrigation productivity in US agriculture using a single factor approach. J. Prod. Anal., 51, 125-136.

Nkegbe, P.K. (2018). Soil and water conservation practices and smallholder farmer multi-activity technical efficiency in northern Ghana. Ghana J. Dev. Stud., 15(1), 53-91.
Nmadu, J.N., Marcus, P.L. (2013). Efficiency of ginger production in selected local government areas of Kaduna State, Nigeria. Int. J. Food Agric. Econ., 1 (2), 39-52.

PFJ (2017). Planting for Food and Jobs: Strategic Plan for implementation (2017-2020). Ministry of Food and Agriculture, Accra, Ghana.

Ricker-Gilbert, J., Jayne, T.S. (2015). Smallholder farmers access to seeds and fertilizer in sub-Saharan Africa. Presentation for the European Commission Workshop on Local level food and nutrition security and the role of subsistence/ smallholder farms. Seville, Spain, September 9-10, 2015.

Sebopetji, T.O., Belete, A. (2009). An application of probit analysis to factors affecting small-scale farmers' decision to credit: A case study of Greater Letaba Municipality in South Africa. Afr. J. Agric. Res., 4(8), 718-723.

Sheahan, M., Barrett, C.B. (2017). Ten striking facts about agricultural input use in sub-Saharan Africa. Food Polic., $67,12-25$.

Sheahan, M., Black, R., Jayne, T. (2013). Are Kenyan farmers underutilizing fertilizer? Implications for input intensification strategies and research. Food Polic., 41, 39-52.

Singh, D.K. (2018). Determinants of dairy farmers' choice of marketing channels in Bihar, India. Agric. Econ. Res. Rev., 31(1), 149-155.

Snapp, S.S., Jayne, T.S., Mhango, W., Benson, T., Ricker-Gilbert, J. (2014). Maize yield response to Nitrogen in Malawi's smallholder production systems. Malawi Strategy Support Program, IFPRI Working Paper 9. Washington DC.

Sulemana, A., Adjei, S.A. (2015). Microfinance impact on agricultural production in developing countries: A study of the Peru district in Ghana. Int. J. Acad. Res. Refl., 3(3), 26-44.

Tanko, M., Ismaila, S., Sadiq, S.A. (2019). Planting for Food and Jobs (PFJ): A panacea for productivity and welfare of rice farmers in northern Ghana. Cogent Econ. Fin., 7(1), 1693121.

Vanlauwe, B., Kihara, J., Chivenge, P., Pypers, P., Coe, R., Six, J. (2011). Agronomic use efficiency of Nitrogen fertilizer in maize-based systems in sub-Saharan Africa within the context of integrated soil fertility management. Plant Soil, 339, 35-50.

Wiredu, A.N., Zeller, M., Diagne, A. (2015). Impact of fertilizer subsidy on land and labour productivity of rice producing households in northern Ghana. Oxford: Centre for the Study of African Economies.

Wongnaa, C.A. (2016). Economic efficiency and productivity of maize farmers in Ghana. PhD Thesis, Department of Agricultural Economics, Agribusiness and Extension, Kwame Nkrumah University of Science and Technology, Kumasi.

WFP (World Food Programme) (2012). Comprehensive food security and vulnerability analysis: Focus on Northern Ghana. Rome, Italy: World Food Programme. 